\title{
The (un)lucky neighbour: differences in export performance across Mexico's states*广
}

\author{
Octavio Escobar \\ Université Paris Dauphine, LEDa \\ IRD, UMR225-DIAL \\ E-mail: octavio.escobar@dauphine.fr
}

\begin{abstract}
This paper studies the reasons behind the export performance of different Mexican states from 1994 to 2002. Mexican exports are divided into two components: (1) foreign market potential; and (2) supply capacity. Results suggest that states that experience an increase in supply capacity are, in most cases, also those with better export expansion. However, results suggest that in most cases, export growth is due mainly to an increase in US demand rather than to an improvement in the states' competitiveness to supply this demand. When looking to the determinants of supply capacity improvements, results suggest the presence of positive neighbouring effects. In other words, part of a state's improvement in the export sector is thanks to its neighbours.
\end{abstract}

Keywords: Trade; Mexico; NAFTA; spatial econometrics

Code JEL: C31; F12; O54

\section{Introduction}

In the mid 1980s Mexico shifted its growth strategy from a policy of industrialization through import substitution to an export-led growth strategy. Trade liberalization policies attempted to encourage investments in the production of tradable goods to exploit Mexico's potential as an export platform to the United States (Moreno-Brid et al., 2005). The Mexican liberalization process accelerated with the signing of the North American Free Trade Agreement (NAFTA) with Canada and the United States (US) which came into effect in January 1994. Less than twelve months later, Mexico faced one of the worst economic crises in its history. The Mexican peso was devalued and Mexican authorities implemented macroeconomic stabilization policies as a response to the financial crisis.

Exports increased considerably after the devaluation of the peso in 1995, which spurred the competitiveness of Mexican products. Indeed, during the period of 1994-2001 Mexico ranked second, just behind China, among those countries with the largest increase in their share of world manufacture exports (Moreno-Brid et al., 2005). According to Blecker (2006) in addition to the devaluation of the peso, other circumstances played an important role in Mexico's export performance from 1996-2000. The first is the fact that NAFTA, apart from opening the US market to Mexican products, guarantees foreign investors' property rights in Mexico. A second circumstance is the economic boom of the US economy in the Clinton era. However, Mexican exports entered into a recession in 2001, partly due to the Mexican authorities' encouragement of a high peso as a means of controlling inflation [Blecker (2006)], and partly due to a slowing down in the US growth rate, pointing to a high elasticity of exports in US income, as suggested by Pacheco-López and Thirlwall (2004). As Figure 1 illustrates, most Mexican exports go to the US market, and its growth rate seems to depend on US demand.

Since the Mexican outward oriented strategy was mainly focused on serving the US market, the reference market for many firms changed with liberalization reforms. From a theoretical model inspired by the Mexican case, Krugman and Elizondo (1996) suggest that as the economy opens, the importance of Federal District as an industrial centre decreases. In other words, liberalization policies weaken the

\footnotetext{
${ }^{*}$ This is a postprint version of an article whose final and definitive version has been published in Papers in Regional Science on 3 Novembre 2010 (http://www.blackwell-synergy.com/doi/abs/10.1111/j.1435-5957.2010.00291.x). The definitive version is available at wileyonlinelibrary.com

${ }^{\dagger}$ I would like to thank Fernando Borraz for providing useful data used on this paper. I am also grateful for comments from two anonymous referees that substantially improved the paper.
} 
Figure 1. Mexico's total exports and Mexico's exports to US (1993 total exports $=100 \%)$

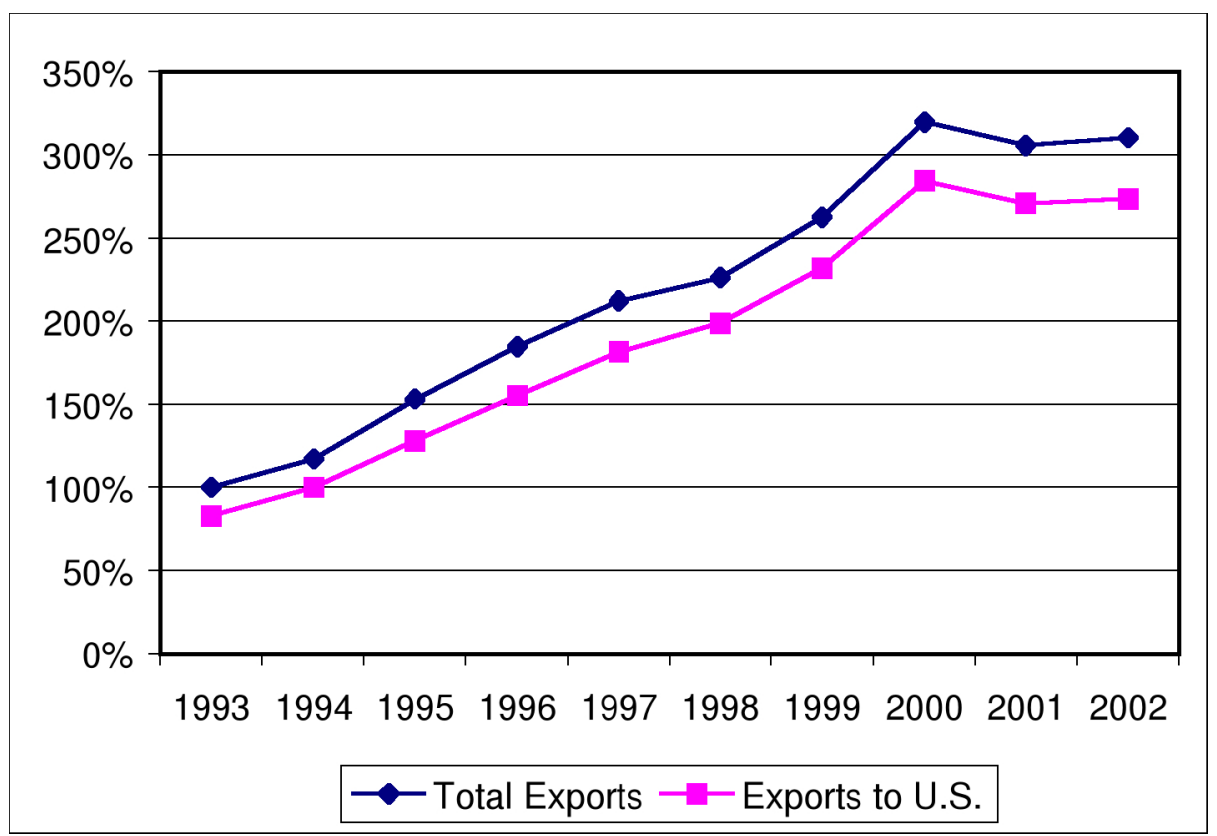

Source: Elaborated by the author with data from INEGI.

forward and backward linkages formed by protection policies, and a dispersion of economic activities takes place. These theoretical findings were supported by Hanson (1998) who studies the effects of opening-up on Mexico's regional economies. Analyzing the effects on regional labour demand, he finds evidence that the pattern of industrial concentration around the capital is changing, and new industrial centres have been created in the northern states to profit from their access to the US market.

Given these facts, the purpose of this paper is to study an important issue regarding Mexico's external sector that has not yet received much attention: the origin of disparities in export performance among Mexican states. Indeed, as Figure 2 illustrates, there are great differences in the export share between Mexican states. Most "exporter" states are located in the north of the country. However, as suggested by Krugman and Elizondo (1996), a dispersion of the export sector activity seems to be taking place. Comparing shares in 1993 and 2000/2002, the importance of the metropolitan region states (the Federal District and the State of Mexico) and Chihuahua as exporters has decreased. To determine the factors behind Mexican states' improvements in export performance, a theoretical model developed by Redding and Venables (2004a) based on a monopolistic competition framework is employed. This model allows for the decomposition of countries' exports into two components. The first relates to shifts in the demand for countries' tradable goods, and the second to changes in countries' supply capacity.

This paper is organized as follows. In section 2, Redding and Venables (2004a) partial equilibrium model is adapted to the Mexican case to develop an estimation framework. Assuming that all Mexican exports go to the US market, exports by Mexican state are presented as a function of their proximity to the US market and of the capacity to supply this market.

Section 3 presents estimation results. Mexican states export performances are decomposed into foreign market potential and supply capacity, and differences across Mexico's states are analyzed. Results suggest that most of the export growth can be explained by shifts in the demand side, measured as market potential. However, states having the better export performances are those that experienced the greatest increases in supply capacity.

Section 4 analyses supply capacity in depth by studying its sources. A theoretical extension to the model is presented that takes into account the general equilibrium process. Then, spatial econometric techniques are introduced to control for spatial linkages and the extended model is estimated. Results suggest that supply capacity is influenced by the economic size and the road infrastructure. Most importantly, results suggest the existence of spatial spillovers that play a positive role in determining supply capacity. Finally, section 5 presents some concluding remarks. 
Figure 2. Mexico's states export share

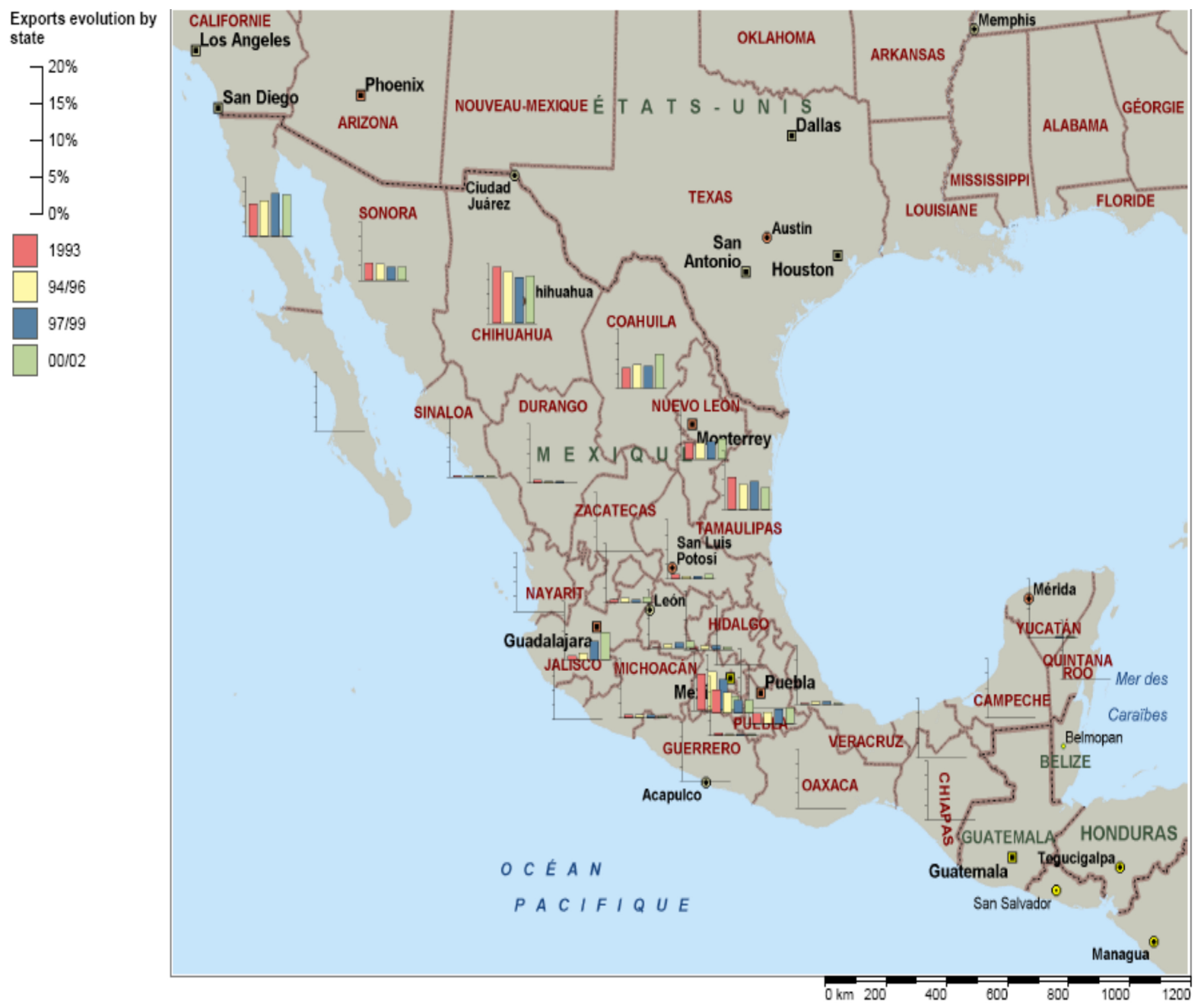

Source: Elaborated by the author with data from Borraz and López-Córdova (2007).

\section{Theory}

The previous section points out two main facts: (1) Mexican export dependency on the US economy, and (2) differences in terms of international trade levels across states, mainly due to differences in their access to the US market. The Dixit-Stiglitz-Krugman model of monopolistic competition and trade in a multi-region setting allows for the decomposition of exports into two components: the first related to market potential, and the second to supply capacity. This theoretical model is employed to analyze the disparities in export performance among Mexican states. The main assumption is that an increase in the expenditure of tradable goods in US should raise the demand of Mexican tradable goods. However, states would not profit from this increase in Mexican goods demand in the same way, due to differences in trade costs. Thus, the objective is to study which states have reacted better to shifts in the demand side.

\section{$2.1 \quad$ US demand}

It is assumed that US consumers have identical preferences. In addition, their utility is given by the consumption of both tradable $\left(C_{u s}^{T}\right)$ and non tradable $\left(C_{u s}^{N T}\right)$ goods. This utility function is then represented by a Cobb-Douglas function:

$$
U_{u s}=\left(C_{u s}^{T}\right)^{\alpha}\left(C_{u s}^{N T}\right)^{1-\alpha}, 0 \leq \alpha \leq 1
$$

We assume that the demand of tradable goods is the aggregate of the demand of tradable goods 
produced in region $i=1, \ldots R$. Moreover, region- $i$ 's firms produce under increasing returns to scale a range of symmetric differentiated goods to provide the US demand. US consumption of tradable goods by sector is represented as standard CES setup:

$$
C_{u s}^{T}=\left[\sum_{i=1}^{R} n_{i} x_{i, u s}^{(\sigma-1) / \sigma}\right]^{\sigma /(\sigma-1)}, 1<\sigma \leq \infty
$$

where $n_{i}$ is the set of varieties produced by region- $i ; x_{i, u s}$ is the US consumption of a single product variety produced in region- $i$; and $\sigma$ is the elasticity of substitution across varieties.

In this framework, the US demand for each variety produced in region- $i$ is a function of the US total expenditure on tradable goods $\left(E_{u s}\right)$, product price $\left(p_{i, u s}\right)$ and a price index given by all tradable goods sold in the US $\left(P_{u s}\right)$. Demand for an individual variety can then be written as:

$$
x_{i, u s}=p_{i, u s}^{-\sigma} E_{u s}\left(P_{u s}\right)^{(\sigma-1)}
$$

where $P_{u s}$ can be formulated as a generalized mean of the number of firms that supply the US market, as well as a function of prices of individual varieties produced by each region:

$$
P_{u s}=\left[\sum_{j=1}^{R} n_{j} p_{j, u s}^{(1-\sigma)}\right]^{1 /(1-\sigma)}
$$

Following the literature, trade costs take the "iceberg" form. It is assumed that region-i's varieties by sector have the same producer price $\left(p_{i}\right)$, and the transportation costs $(\tau)$ introduce a spread between the domestic and foreign price of any variety produced in region- $i$. The value of region- $i$ 's exports to the US is therefore given by:

$$
X_{i, u s}=n_{i} p_{i} x_{i, u s}=n_{i} p_{i}^{(1-\sigma)} \tau_{i, u s}^{(1-\sigma)} E_{u s}\left(P_{u s}\right)^{(\sigma-1)}
$$

As we can see in equation 5 , the value of region-i's total exports depends on both region-i and US characteristics. Thus, the term $E_{u s}\left(P_{u s}\right)^{(\sigma-1)}$ is completely exogenous to region- $i$, it depends on the US tradable goods market, and it will be the same for all Mexican states. Following Redding and Venables (2004a), this term will be considered as the US market capacity $\left(m_{u s}\right)$. On the other

hand, the term $n_{i} p_{i}^{(1-\sigma)} \tau_{i, u s}^{(1-\sigma)}$ depends completely on region- $i$. Thus, differences in exports across Mexican states are mainly due to their differences in the number of varieties produced by each state, in their price competitiveness, as well as on differences in the costs of delivery to the US market. Also following Redding and Venables (2004a), the term $n_{i} p_{i}^{(1-\sigma)}$ is considered as region- $i$ 's supply capacity $\left(s c_{i}\right)$. Finally, equation 5 also shows that varieties' demand is more influenced by trade costs when there is a high elasticity of substitution. Equation 5 can be rewritten as:

$$
X_{i, u s}=s_{i} \phi_{i, u s} m_{u s}
$$

where $\phi_{i, u s}=\tau_{i, u s}^{(1-\sigma)}$.

Finally, we can define the term $M_{i}=\phi_{i, u s} m_{u s}$ as region- $i$ foreign market access or real foreign market potential (Head and Mayer, 2004; Redding and Venables, 2004a). Then export performance depends on the supply capacity and on the real foreign market potential:

$$
X_{i, u s}=s_{i} M_{i}
$$

\section{Export performance}

According to our theoretical model, two elements are necessary to determine the export performance of Mexican states: supply capacity and US market potential. To estimate these two elements, methodology implemented by Redding and Venables (2004b) is employed. In their work Redding and Venables (2004b) use a gravity model to compute supply capacity as the fixed effects of the exporter country and market 
capacity as the fixed effects of the importer partner. Indeed, from equation 6 , the following model is specified:

$$
\ln \left(X_{i j t}\right)=\alpha+\beta \ln \left(\text { distance }_{i j}\right)+\gamma \text { Border }_{i j}+F E_{i}+F E_{j}+u_{i j t}
$$

Following the literature, bilateral distance and common border are employed as a proxy for obtaining transport costs. More precisely, transportation costs are computed as $\phi_{i j}=\operatorname{distance}_{i j} \widehat{\beta} \cdot \exp \left(\widehat{\gamma} B\right.$ order $\left.r_{i j}\right)$. Supply capacity can be computed from state- $i$ fixed effects, $s_{i}=\exp \left(F E_{i}\right)$. Finally, the US market capacity is obtained from the US importer dummy $m_{u s}=\exp \left(F E_{u s}\right)$. Once transportation costs and US market capacity are estimated, state- $i$ real US market potential is obtained from $M_{i}=\phi_{i, u s} m_{u s}$.

\subsection{Data sources and estimation strategy}

The sample of Mexican exports is composed by the thirty two Mexican federative entities, and the period of study is from 1994 to 2002. Equation 4 shows that the price index of US imports is affected by the number of varieties sold in the country. Hence, it is pertinent to take into account the largest number of these varieties. We can include in the sample the main trade partners of the US. Indeed, Canada, Japan, China and Mexico account for more than $52 \%$ of US manufacturing imports for the 1994-2002 period. However, to have a more accurate measure of US market capacity, in addition to these four countries, equation 8 is estimated using bilateral trade data between the OECD member countries plus the main US trade partners: China, South Korea and Taiwan (see appendix A for more details). Countries in the sample account for more than $82 \%$ of US manufacturing imports for the period 1994-2002.

Except for the Mexican data on exports and distance to US, bilateral trade data and distance data was obtained from the CEPII Trade, Production and Bilateral Protection Database [Mayer and Zignago (2005)] and from the CEPII distance databases, respectively. Given that Mexican regional export data, obtained from Borraz and López-Córdova (2004), is not available at sector level, CEPII trade flows are grouped into a total bilateral trade flows. CEPII distances database proposes different distance measures. Following Head and Mayer (2002) formula, the population weighted distance between the 25 most important agglomerations is employed; where distances between agglomerations are calculated following the great circle formula.

Head and Mayer (2002) formula is also employed to measure the distance between a Mexican state and the US. However, distance is measured as the weighted road distance from the state's most important urban agglomerations (those over 150000 inhabitants) to the nearest border crossing. This measure is preferable to weighted great circle distance to 25 most important agglomeration, since the latter penalizes the states located at the northwest of Mexico suggesting that some non-border states can be closer to US than Baja California, which is unrealistic. In addition, shipments by road represented over 70 per cent of Mexican shipments to United States ${ }^{1}$.

Three panel regressions of the equation 8 model are implemented to compute supply capacity and foreign market potential for three years periods. The first concerns 1994-1996, which corresponds to the Mexican financial crisis; a second concerns a post-crisis period from 1997 to 1999; and the last concerns the downturn of the US economy from 2000-2002. In addition, the use of three regressions allows us to employ the techniques of seemingly unrelated estimation to compare the differences of regressors between the three periods.

Regression results are presented in Table 1. As expected, the coefficient on distance is negative, which indicates that the further away state- $i$ is from the US, the less it exports. We can also see that the distance coefficient value initially decreases and then increases between the second and third periods, but these variations are not important. Distance coefficient value is near to -1 , which is a frequent find among gravity equations literature [Disdier and Head (2003); Head and Mayer (2002)]. The common border coefficient value increases over time, but this increase is not significant.

According to the model, exporter fixed effects represents the supply capacity of a region. We can see that for most of the Mexican states, their coefficient increase between the first and second periods, but it decreases between the second and third periods. We can also see that the states that form Mexico's industrial belt (the Federal District and the State of Mexico) are among the three states that have the most important supply capacity, however, both of them were doubled by Jalisco, who reports the highest supply capacity for the last period. Table 1 also reports the supply capacity evolution of the US, Canada, Japan and China. Concerning the US and Canada, the evolution is similar to the evolutions of Mexican states. However, China experiences a constant increase in supply capacity, while Japan supply capacity

\footnotetext{
${ }^{1}$ Source: North American Transportation Statistics, http://nats.sct.gob.mx/
} 
Table 1 . Gravity regression results

\begin{tabular}{|c|c|c|c|c|c|c|}
\hline \multirow{2}{*}{$\begin{array}{l}\text { Dependent Variable: Exports } \\
\text { Distance }\end{array}$} & \multicolumn{2}{|c|}{ 1994-1996 } & \multicolumn{2}{|c|}{ 1997-1999 } & \multicolumn{2}{|c|}{$2000-2002$} \\
\hline & -1.010 & $(0.048)^{* *}$ & -0.997 & $(0.046)^{* *}$ & -1.000 & $(0.045)^{* *}$ \\
\hline Border & 0.269 & $(0.110) *$ & 0.273 & $(0.110)^{*}$ & 0.287 & $(0.110)^{* *}$ \\
\hline \multicolumn{7}{|l|}{ Mexican states (supply capacity) } \\
\hline MEX & -1.416 & $(0.159)^{* *}$ & -1.263 & $(0.156)^{* *}$ & -2.008 & $(0.151)^{* *}$ \\
\hline JAL & -2.936 & $(0.159) * *$ & -1.706 & $(0.156) * *$ & -1.419 & $(0.151)^{* *}$ \\
\hline $\mathrm{DF}^{c a p}$ & -2.015 & $(0.159)^{* *}$ & -1.972 & $(0.156)^{* *}$ & -2.143 & $(0.150) * *$ \\
\hline PUE & -2.547 & $(0.159)^{* *}$ & -1.945 & $(0.156)^{* *}$ & -1.976 & $(0.151)^{* *}$ \\
\hline $\mathrm{COA}^{n b}$ & -2.905 & $(0.174)^{* *}$ & -2.581 & $(0.171)^{* *}$ & -2.252 & $(0.166)^{* *}$ \\
\hline $\mathrm{SON}^{n b}$ & -3.179 & $(0.173)^{* *}$ & -2.988 & $(0.169) * *$ & -3.059 & $(0.164)^{* *}$ \\
\hline GTO & -3.629 & $(0.161)^{* *}$ & -3.047 & $(0.158) * *$ & -2.866 & $(0.152)^{* *}$ \\
\hline $\mathrm{TAM}^{n b}$ & -3.435 & $(0.188)^{* *}$ & -2.908 & $(0.184)^{* *}$ & -3.246 & $(0.179)^{* *}$ \\
\hline $\mathrm{CHI}^{n b}$ & -3.523 & $(0.211)^{* *}$ & -3.208 & $(0.205)^{* *}$ & -3.262 & $(0.200)^{* *}$ \\
\hline QRO & -3.777 & $(0.161)^{* *}$ & -3.372 & $(0.158) * *$ & -3.607 & $(0.152)^{* *}$ \\
\hline AGS & -3.874 & $(0.163)^{* *}$ & -3.572 & $(0.160) * *$ & -3.320 & $(0.154)^{* *}$ \\
\hline YUC & -4.241 & $(0.157)^{* *}$ & -3.427 & $(0.154) * *$ & -3.213 & $(0.148)^{* *}$ \\
\hline $\mathrm{NLN}^{n b}$ & -4.017 & $(0.192)^{* *}$ & -3.465 & $(0.187)^{* *}$ & -3.431 & $(0.182)^{* *}$ \\
\hline MIC & -3.700 & $(0.159)^{* *}$ & -3.618 & $(0.156) * *$ & -3.923 & $(0.151)^{* *}$ \\
\hline VER & -3.707 & $(0.159) * *$ & -3.630 & $(0.156) * *$ & -4.139 & $(0.151)^{* *}$ \\
\hline SLP & -4.310 & $(0.164)^{* *}$ & -3.919 & $(0.161)^{* *}$ & -3.704 & $(0.156)^{* *}$ \\
\hline MOR & -3.976 & $(0.158) * *$ & -3.909 & $(0.156) * *$ & -4.174 & $(0.150) * *$ \\
\hline SIN & -4.314 & $(0.160)^{* *}$ & -4.051 & $(0.157)^{* *}$ & -4.109 & $(0.151)^{* *}$ \\
\hline DGO & -4.491 & $(0.163)^{* *}$ & -4.321 & $(0.160)^{* *}$ & -4.797 & $(0.155)^{* *}$ \\
\hline $\mathrm{BCS}$ & -4.741 & $(0.157) * *$ & -4.869 & $(0.154) * *$ & -5.003 & $(0.149)^{* *}$ \\
\hline $\mathrm{BCN}^{n b}$ & -5.423 & $(0.266)^{* *}$ & -4.801 & $(0.256) * *$ & -4.910 & $(0.252)^{* *}$ \\
\hline TLA & -5.498 & $(0.159)^{* *}$ & -4.698 & $(0.157) * *$ & -4.949 & $(0.151)^{* *}$ \\
\hline $\mathrm{CHS}$ & -4.769 & $(0.157) * *$ & -4.832 & $(0.154) * *$ & -5.829 & $(0.148) * *$ \\
\hline $\mathrm{HGO}$ & -5.629 & $(0.160)^{* *}$ & -4.731 & $(0.157)^{* *}$ & -5.421 & $(0.151)^{* *}$ \\
\hline $\mathrm{ZAC}$ & -5.605 & $(0.163)^{* *}$ & -5.537 & $(0.160) * *$ & -5.866 & $(0.155)^{* *}$ \\
\hline GRO & -5.987 & $(0.157)^{* *}$ & -5.589 & $(0.154)^{* *}$ & -5.521 & $(0.149)^{* *}$ \\
\hline CAM & -5.979 & $(0.157)^{* *}$ & -5.974 & $(0.154)^{* *}$ & -5.400 & $(0.148)^{* *}$ \\
\hline OAX & -5.750 & $(0.157) * *$ & -6.004 & $(0.155) * *$ & -6.425 & $(0.149)^{* *}$ \\
\hline NAY & -6.250 & $(0.158)^{* *}$ & -5.926 & $(0.155)^{* *}$ & -6.740 & $(0.149)^{* *}$ \\
\hline TAB & -6.803 & $(0.157)^{* *}$ & -6.104 & $(0.154)^{* *}$ & -6.285 & $(0.149)^{* *}$ \\
\hline $\mathrm{COL}$ & -6.861 & $(0.158)^{* *}$ & -6.046 & $(0.155)^{* *}$ & -6.671 & $(0.149)^{* *}$ \\
\hline QTR & -7.341 & $(0.157)^{* *}$ & -6.460 & $(0.154) * *$ & -6.707 & $(0.148)^{* *}$ \\
\hline \multicolumn{7}{|c|}{ Other exporters (supply capacity) } \\
\hline USA & 3.815 & $(0.140)^{* *}$ & 3.906 & $(0.140) * *$ & 3.800 & $(0.137)^{* *}$ \\
\hline CAN & 1.251 & $(0.150)^{* *}$ & 1.223 & $(0.147)^{* *}$ & 1.167 & $(0.161)^{* *}$ \\
\hline $\mathrm{CHN}$ & 2.081 & $(0.148)^{* *}$ & 2.376 & $(0.135)^{* *}$ & 2.789 & $(0.124)^{* *}$ \\
\hline \multicolumn{7}{|l|}{ Importers (market capacity) } \\
\hline USA & 2.450 & $(0.168)^{* *}$ & 2.698 & $(0.176)^{* *}$ & 3.040 & $(0.181)^{* *}$ \\
\hline CAN & 0.079 & $(0.158)$ & 0.304 & $(0.165)$ & 0.601 & $(0.172)^{* *}$ \\
\hline JPN & 1.315 & $(0.186)^{* *}$ & 1.249 & $(0.197)^{* *}$ & 1.388 & $(0.211)^{* *}$ \\
\hline DEU & 1.009 & $(0.186) * *$ & 1.008 & $(0.187) * *$ & 1.099 & $(0.178)^{* *}$ \\
\hline Observations & 1824 & & 1824 & & 1824 & \\
\hline R-squared & 0.92 & & 0.93 & & 0.93 & \\
\hline
\end{tabular}

decreases. It is not surprising that this country overtook Japan as the second largest manufacturing exporter to US in 2002.

We have seen that market capacity can be computed from the importer fixed effects as: $m_{j}=$ $\exp \left(I m p_{j}\right)$. Table 1 illustrates the fixed effect evolution of Mexico's NAFTA partners as well as of the other two major world markets: Japan and Germany. We can see the big difference in terms of market capacity between the US and the other countries. In addition, US market capacity increases by $28 \%$ between the first and second periods, moreover it experiences an increase of more than $40 \%$ between the second and third periods.

We have seen that results look rather stable across the three time periods. In order to look for differences across time periods, a set of tests for the equality of the coefficients is computed and some of them are reported in Table 2. We can see that the null of the equality between regressions are rejected, which, according to our model, suggest that at least one of supply capacity, market capacity and trade 
Table 2. Tests of equality between gravity regressions

\begin{tabular}{|c|c|c|}
\hline HO: Equality of regressors & $\begin{array}{l}\text { ross time) } \\
\chi^{2}(100)=40853.89\end{array}$ & Prob $>\chi^{2}=0.00$ \\
\hline HO: Distance effects const & $\chi^{2}(2)=1.43$ & Prob $>\chi^{2}=0.49$ \\
\hline HO: Contiguity effects con & $\chi^{2}(2)=0.21$ & Prob $>\chi^{2}=0.90$ \\
\hline $\begin{array}{c}\text { HO: Supply capacity constc } \\
\text { AGS } \\
\text { BCN } \\
\text { BCS } \\
\text { CAM } \\
\text { COA } \\
\text { COL } \\
\text { CHS } \\
\text { CHI } \\
\text { DF } \\
\text { DGO } \\
\text { GTO } \\
\text { GRO } \\
\text { HGO } \\
\text { JAL } \\
\text { MEX } \\
\text { MIC } \\
\text { MOR } \\
\text { NAY } \\
\text { NLN } \\
\text { OAX } \\
\text { PUE } \\
\text { QRO } \\
\text { QTR } \\
\text { SLP } \\
\text { SIN } \\
\text { SON } \\
\text { TAB } \\
\text { TAM } \\
\text { TLA } \\
\text { VER } \\
\text { YUC } \\
\text { ZAC }\end{array}$ & $\begin{array}{l}\chi^{2}(2)=65.90 \\
\chi^{2}(2)=89.79 \\
\chi^{2}(2)=15.84 \\
\chi^{2}(2)=169.78 \\
\chi^{2}(2)=72.80 \\
\chi^{2}(2)=674.66 \\
\chi^{2}(2)=503.86 \\
\chi^{2}(2)=35.58 \\
\chi^{2}(2)=16.42 \\
\chi^{2}(2)=126.93 \\
\chi^{2}(2)=188.91 \\
\chi^{2}(2)=91.79 \\
\chi^{2}(2)=789.42 \\
\chi^{2}(2)=854.00 \\
\chi^{2}(2)=300.90 \\
\chi^{2}(2)=52.89 \\
\chi^{2}(2)=40.10 \\
\chi^{2}(2)=438.53 \\
\chi^{2}(2)=120.91 \\
\chi^{2}(2)=108.50 \\
\chi^{2}(2)=212.35 \\
\chi^{2}(2)=133.65 \\
\chi^{2}(2)=536.84 \\
\chi^{2}(2)=89.45 \\
\chi^{2}(2)=44.00 \\
\chi^{2}(2)=21.45 \\
\chi^{2}(2)=329.93 \\
\chi^{2}(2)=167.81 \\
\chi^{2}(2)=431.36 \\
\chi^{2}(2)=134.80 \\
\chi^{2}(2)=388.55 \\
\chi^{2}(2)=52.91 \\
\end{array}$ & $\begin{array}{l}\text { Prob }>\chi^{2}=0.00 \\
\text { Prob }>\chi^{2}=0.00 \\
\text { Prob }>\chi^{2}=0.00 \\
\text { Prob }>\chi^{2}=0.00 \\
\text { Prob }>\chi^{2}=0.00 \\
\text { Prob }>\chi^{2}=0.00 \\
\text { Prob }>\chi^{2}=0.00 \\
\text { Prob }>\chi^{2}=0.00 \\
\text { Prob }>\chi^{2}=0.00 \\
\text { Prob }>\chi^{2}=0.00 \\
\text { Prob }>\chi^{2}=0.00 \\
\text { Prob }>\chi^{2}=0.00 \\
\text { Prob }>\chi^{2}=0.00 \\
\text { Prob }>\chi^{2}=0.00 \\
\text { Prob }>\chi^{2}=0.00 \\
\text { Prob }>\chi^{2}=0.00 \\
\text { Prob }>\chi^{2}=0.00 \\
\text { Prob }>\chi^{2}=0.00 \\
\text { Prob }>\chi^{2}=0.00 \\
\text { Prob }>\chi^{2}=0.00 \\
\text { Prob }>\chi^{2}=0.00 \\
\text { Prob }>\chi^{2}=0.00 \\
\text { Prob }>\chi^{2}=0.00 \\
\text { Prob }>\chi^{2}=0.00 \\
\text { Prob }>\chi^{2}=0.00 \\
\text { Prob }>\chi^{2}=0.00 \\
\text { Prob }>\chi^{2}=0.00 \\
\text { Prob }>\chi^{2}=0.00 \\
\text { Prob }>\chi^{2}=0.00 \\
\text { Prob }>\chi^{2}=0.00 \\
\text { Prob }>\chi^{2}=0.00 \\
\text { Prob }>\chi^{2}=0.00\end{array}$ \\
\hline $\begin{array}{r}\text { HO: Market capacity const } \\
\text { USA }\end{array}$ & $\chi^{2}(2)=18.94$ & Prob $>\chi^{2}=0.00$ \\
\hline
\end{tabular}

Table notes: Tests based on results reported on Table 1.

costs vary with the time. When computing the Wald tests of equality for the distance coefficients between the three regressions, results suggest that distance effects are time invariant for the period of study. A similar result is found for the common border variable. However, when proceeding to analyze the equality of supply capacity for the Mexican states, the null is rejected. In other words, supply capacity variations are significant between the three periods of study. The same conclusion is obtained from the test of equality for the US importer fixed effect. Thus, improvements in US market capacity are significant across time.

\subsection{Exports decomposition}

Gravity equation allows us to compute the US market capacity the trade costs and the Mexican states supply capacity. Once we have these elements, we can proceed to compute the US market potential for each state, and to analyze their export performance. To compute the foreign market potential for each state we use the following equation: $M_{i}=\phi_{i, u s} m_{u s}$. Once the foreign market potential is computed, export performance can be decomposed into supply capacity growth and foreign market potential growth. We can then proceed to analyze the growth of average exports between period 1 (1994-1996) and period 2 (1997-1999), between periods 2 and 3 (2000-2002), and finally, between periods 1 and 3 .

Results are presented in Table 3, where states are sorted from best to worst export performance 
between periods 1 and 3. From the average performance (last row of Table 3), we can see that exports grow considerably between periods 1 and 2, but slowed considerably between periods 2 and 3 . This change in growth is explained mainly by a slowdown in supply capacity. Indeed, between periods 1 and 2 , the average supply capacity grew by $55.4 \%$, while it decreased by $11.6 \%$ between periods 2 and 3 . Between the initial and final periods of study, average exports grew by about $103 \%$, but most of this boom can be explained by an significant increase in foreign market potential. Moreover, supply capacity decreased for one third of the Mexican states between the initial and final periods by about $30 \%$. We can also see that the foreign market potential increases by $96 \%$ between the initial and the last period. This result is two times bigger than the one reported by Redding and Venables (2004a) for Mexico North America market potential for the period 1982/85 - 1994/97. Mayer (2008) computes two different measures of foreign market potential for different countries for the 1960-2003 period. From his database, Mexico's foreign market potentials are computed for the same three time periods to compare them with the results reported Table 3. Mayer's (2008) average foreign market potential for Mexico increases for about $40 \%$ between the 1994/96 and 1997/99 periods and for about 54\% between the 1997/99 and $2000 / 02$ periods, for an overall growth of about $116 \%$ between the first and the third periods. These results are very similar to those reported in Table 3, which highlights the weight of the US market over the overall foreign market potential for Mexico.

Looking at individual states, we can see that states with the highest levels of exports did not experience the highest average growth in exports. As Table 3 illustrates, the northern border state that experienced the best performance in exports between periods 1 and 3 is Coahuila, ranked sixth in terms of export growth. Jalisco has the best export improvement; indeed, this state increased its exports by over $500 \%$, explained by a considerable improvement in supply capacity that places it as the states with the highest supply capacity.

At the opposite extreme, we can find the poorest Mexican states: Oaxaca and Chiapas. Between periods 1 and 3, these states experienced a export reduction despite of the important increase in foreign market potential. It is important to point out that between the second and third periods, twenty three states $(72 \%)$ showed a decrease in their supply capacity, among them the country's capital and four of six northern border states.

Table 3 shows that differences across Mexican states in export performances are mainly driven by differences in supply capacity improvements. This opens the way for the next section which explores the determinants of supply capacity.

Results are also summarized in figures 3 and 4 , which draws the spatial distribution of export performance and supply capacity improvements between periods 1 and 3. Concerning export growth, Figure 3 shows that states having a weaker export performance are usually neighbors of at least another state also experiencing a poor export performance. On the other hand, states achieving the strongest levels of export improvements share a border with at least one state with important export growth. However, in both cases, the states can be located at the north or at the south of the country. Figure 4 shows the improvements in supply capacity. We can see that this map is very similar to that of export growth. This opens the way for the next section which explores the determinants of supply capacity. In other words, both figures show that states having the worst export performance and the lowest supply capacity growth are usually neighbors of another state with similar a performance. We can see that in most cases the opposite is also true. Thus, we suspect a neighbor's effect on a state's performance.

\section{The determinants of supply capacity}

The main objective of this section is to clarify the main components of supply capacity. As indicated in the theoretical framework presented previously, supply capacity is a function of the number of varieties produced and of production prices. It is then expected that variables measuring economic size and factor endowments are related to supply capacity. However, as pointed out by Redding and Venables (2004a), supply capacity could also be dependent on real market potential. Indeed, an increase in foreign market potential increases the potential returns of export activities; thus an expansion of the export sector is expected, having some impact on supply capacity. To take this endogeneity into account, Redding and Venables (2004a) applied a simple general equilibrium feature that captures the opportunity costs of resources used in the export sector, summarized by the following equation:

$$
\widehat{X}_{i}=\widehat{a}_{i}-\widehat{c}_{i} \omega+\left[\widehat{M}_{i}+(1-\sigma) \widehat{t}_{i}\right] \frac{(1+\omega)}{\sigma}
$$


Table 3. Components of export growth

\begin{tabular}{|c|c|c|c|c|c|c|c|c|c|}
\hline \multirow[b]{2}{*}{ State } & \multicolumn{3}{|c|}{$\begin{array}{c}\text { Period } 1-2 \\
(1994-1996)-(1997-1999)\end{array}$} & \multicolumn{3}{|c|}{$\begin{array}{c}\text { Period } 2-3 \\
(1997-1999)-(2000-2002)\end{array}$} & \multicolumn{3}{|c|}{$\begin{array}{c}\text { Period } 1-3 \\
(1994-1996)-(2000-2002)\end{array}$} \\
\hline & $\begin{array}{r}\text { Exports } \\
\text { growth } \\
(\%)\end{array}$ & $\begin{array}{r}\text { Supply } \\
\text { Capacity } \\
(\%)\end{array}$ & $\begin{array}{r}\text { Market } \\
\text { access } \\
(\%)\end{array}$ & $\begin{array}{r}\text { Exports } \\
\text { growth } \\
(\%)\end{array}$ & $\begin{array}{r}\text { Supply } \\
\text { Capacity } \\
(\%)\end{array}$ & $\begin{array}{r}\text { Market } \\
\text { access } \\
(\%)\end{array}$ & $\begin{array}{r}\text { Exports } \\
\text { growth } \\
(\%)\end{array}$ & $\begin{array}{r}\text { Supply } \\
\text { Capacity } \\
(\%)\end{array}$ & $\begin{array}{r}\text { Market } \\
\text { access } \\
(\%)\end{array}$ \\
\hline JAL & 279.8 & 242.1 & 40.8 & 66.9 & 33.2 & 39.8 & 533.9 & 355.9 & 96.8 \\
\hline YUC & 149.3 & 125.7 & 42.0 & 53.5 & 23.9 & 39.5 & 282.7 & 179.5 & 98.2 \\
\hline GTO & 99.6 & 79.0 & 40.5 & 52.1 & 19.8 & 39.9 & 203.7 & 114.5 & 96.5 \\
\hline QTR & 190.2 & 141.3 & 42.2 & -1.9 & -21.9 & 39.5 & 184.8 & 88.5 & 98.3 \\
\hline CAM & 20.8 & 0.5 & 41.8 & 128.6 & 77.5 & 39.6 & 176.1 & 78.4 & 98.0 \\
\hline $\mathrm{COA}^{n b}$ & 58.2 & 38.3 & 38.9 & 74.4 & 39.0 & 40.3 & 175.9 & 92.1 & 94.8 \\
\hline SLP & 70.1 & 47.8 & 40.0 & 57.1 & 24.0 & 40.0 & 167.2 & 83.3 & 96.0 \\
\hline $\mathrm{NLN}^{n b}$ & 101.7 & 73.7 & 37.7 & 29.0 & 3.5 & 40.5 & 160.3 & 79.7 & 93.5 \\
\hline PUE & 112.7 & 82.6 & 40.8 & 20.7 & -3.1 & 39.8 & 156.8 & 77.0 & 96.8 \\
\hline AGS & 56.7 & 35.3 & 40.2 & 62.2 & 28.7 & 40.0 & 154.1 & 74.0 & 96.2 \\
\hline TLA & 148.3 & 122.6 & 40.7 & -0.8 & -22.2 & 39.8 & 146.2 & 73.2 & 96.8 \\
\hline GRO & 72.7 & 48.9 & 41.4 & 42.4 & 7.0 & 39.7 & 146.0 & 59.4 & 97.5 \\
\hline $\mathrm{BCN}^{n b}$ & 106.9 & 86.3 & 33.8 & 14.5 & -10.3 & 41.5 & 136.8 & 67.0 & 89.3 \\
\hline TAB & 124.3 & 101.2 & 41.4 & 5.0 & -16.6 & 39.7 & 135.6 & 67.9 & 97.5 \\
\hline $\mathrm{CHI}^{n b}$ & 56.7 & 37.0 & 36.5 & 20.9 & -5.3 & 40.8 & 89.4 & 29.8 & 92.2 \\
\hline SIN & 52.8 & 30.1 & 40.7 & 19.3 & -5.6 & 39.8 & 82.2 & 22.8 & 96.7 \\
\hline QRO & 77.9 & 49.9 & 40.4 & 0.5 & -20.9 & 39.9 & 78.9 & 18.5 & 96.5 \\
\hline $\mathrm{TAM}^{n b}$ & 94.3 & 69.4 & 37.9 & -9.0 & -28.7 & 40.5 & 76.9 & 20.8 & 93.7 \\
\hline $\mathrm{COL}$ & 159.1 & 125.9 & 41.1 & -32.9 & -46.5 & 39.7 & 73.9 & 20.9 & 97.2 \\
\hline $\mathrm{SON}^{n b}$ & 39.9 & 21.0 & 39.1 & 20.0 & -6.9 & 40.2 & 67.9 & 12.7 & 95.0 \\
\hline $\mathrm{HGO}$ & 145.8 & 145.5 & 40.6 & -32.0 & -49.8 & 39.9 & 67.1 & 23.1 & 96.7 \\
\hline $\mathrm{DF}^{c a p}$ & 20.1 & 4.4 & 40.8 & 8.7 & -15.7 & 39.8 & 30.5 & -12.0 & 96.9 \\
\hline MOR & 24.6 & 6.9 & 41.0 & 0.2 & -23.3 & 39.8 & 24.9 & -18.0 & 97.1 \\
\hline BCS & 4.1 & -12.0 & 41.5 & 10.7 & -12.5 & 39.7 & 15.3 & -23.0 & 97.6 \\
\hline $\mathrm{ZAC}$ & 25.1 & 7.0 & 40.1 & -8.4 & -28.0 & 40.0 & 14.7 & -23.0 & 96.1 \\
\hline MIC & 20.7 & 8.5 & 40.8 & -6.2 & -26.3 & 39.8 & 13.3 & -20.0 & 96.8 \\
\hline DGO & 40.0 & 18.5 & 40.1 & -20.2 & -37.9 & 40.0 & 11.7 & -26.4 & 96.1 \\
\hline VER & 20.0 & 8.0 & 40.8 & -23.8 & -39.9 & 39.8 & -8.5 & -35.1 & 96.9 \\
\hline NAY & 65.3 & 38.3 & 41.1 & -47.1 & -55.7 & 39.8 & -12.5 & -38.7 & 97.2 \\
\hline MEX & 34.1 & 16.5 & 40.8 & -39.8 & -52.5 & 39.8 & -19.2 & -44.7 & 96.9 \\
\hline OAX & -3.5 & -22.4 & 41.2 & -22.4 & -34.4 & 39.7 & -25.2 & -49.1 & 97.3 \\
\hline CHS & 8.3 & -6.1 & 41.7 & -52.4 & -63.1 & 39.6 & -48.5 & -65.4 & 97.8 \\
\hline Average & 77.4 & 55.4 & 40.3 & 12.2 & -11.6 & 39.9 & 102.9 & 40.1 & 96.3 \\
\hline
\end{tabular}

Table notes: export growth is the growth of average exports by state between two time periods. Supply capacity and US market access growth are computed from results reported in Table 1. Mexican states sorted from high to low exports growth between period 1-3. cap superscript refers to Mexican capital and most important economic center. $n b$ superscript refers to Northern border states.

where $a_{i}$ is a measure of the size of the economy; $c_{i}$ is a measure of comparative costs in the export sector of region- $i ; \omega$ is the price elasticity of export supply; $t_{i}$ is the total expenditure on internal transport costs; and $\widehat{\cdot}$ denotes a proportional deviation from a reference point. It is important to point out that a less than proportional relationship between foreign market potential and supply capacity is expected. Thus, the coefficient market potential is expected to be less than one: $\sigma>(1+\omega)$. Indeed, an increase in export volume requires an increase in production resources which would be drawn from non export sectors. This production factor demand increase in turn increases prices and, consequently, deteriorates supply capacity.

Other expected results are the following ones: an increase in internal trade costs have a negative impact on export performances given that $\sigma>1$; domestic size increases exports volume; and high costs means that a lower volume of exports is supplied for a given price (Redding and Venables, 2004a).

\section{$5 \quad$ Empirical specification and data sources}

The sample subject to empirical specification is composed of a panel of annual data of the 32 Mexican states for 1994-2002. The empirical specification of equation 9 takes the following form:

$$
X_{i}(t)=z_{i}(t) \beta+u_{i}(t)
$$

where the dependent variable is the $\log$ of total exports of state $i=1, \ldots, N$ for a year $t=1, \ldots, T$. $X_{i}(t)$ 
Figure 3. Exports growth 1994/96 -1999/2002

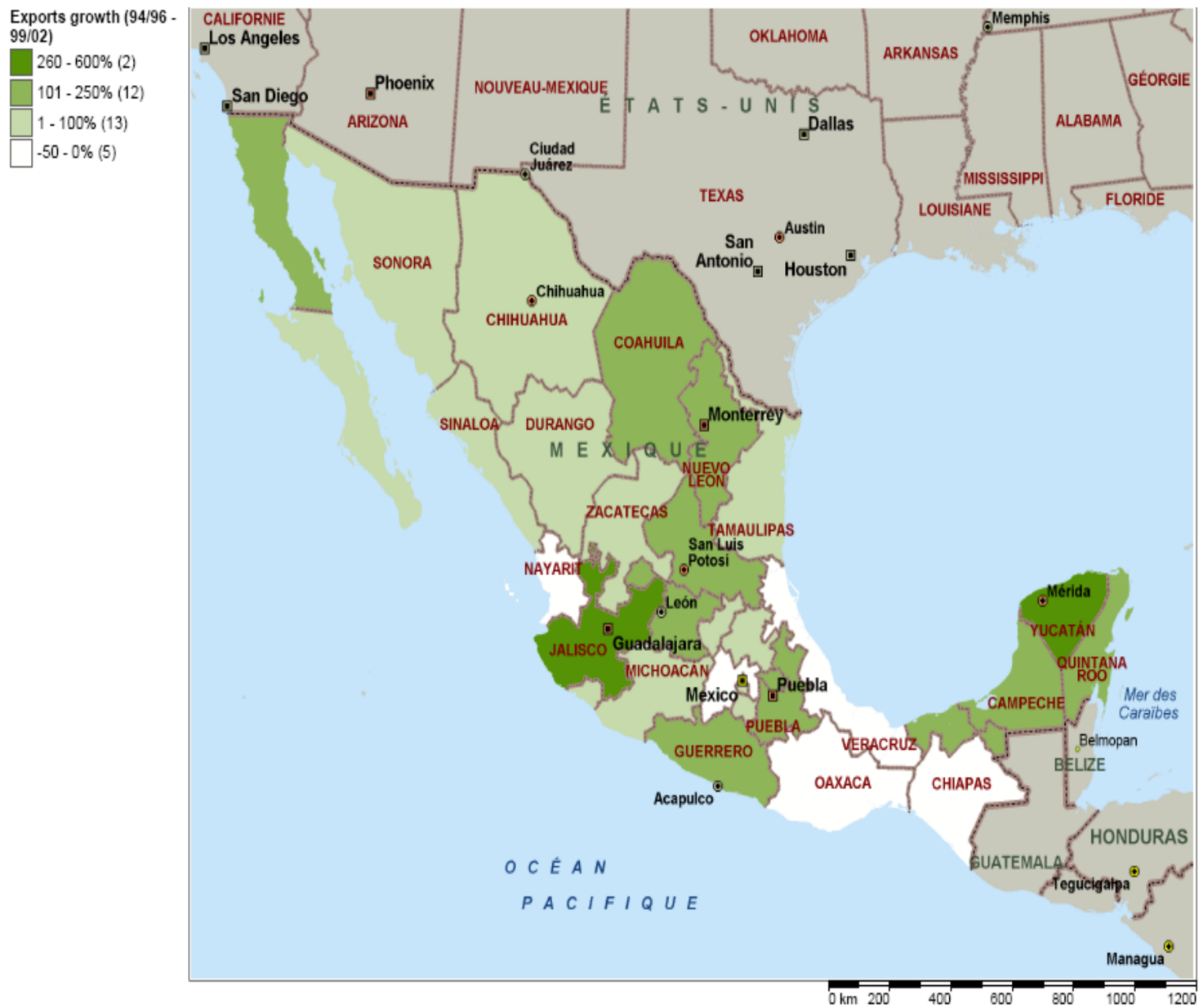

Source: Elaborated by the author with data from Borraz and López-Córdova (2007).

is then a $N \times 1$ vector of observations in a year $t . z_{i}(t)$ is the $N \times k$ matrix of observations on $k$ exogenous variables in year $t$. Finally, $u_{i}(t)$ is an $N \times 1$ vector of disturbances in period $t$.

Following on from the previous section, the exogenous variables considered are measures of economic size, measures of export sector comparative costs or competitiveness, measures of internal transportation costs and the foreign market potential variable. Unless otherwise indicated, independent variables are introduced in logarithmic transformation. State- $i$ real GDP and population are employed to measure economic size. To capture the competitiveness of the export sector, variables related productions costs are employed. Finally, domestic trade costs are measured by road infrastructure. Indeed, given that most of shipments to US are made by road, improvements in the road network can lead to a improvements in trade costs as suggested by Martin and Rogers (1995). The road network for each state is measured as the square kilometers of the state's routes over the state's area.

The spatial concentration of industrial activities can be a source of positive or negative externalities (Fujita et al., 1999). On one hand, supply capacity can be improved by positive externalities as technological spillovers, access to infrastructure and to specialized labor, backward linkages, etc. On the other hand, negative externalities as congestion effects, as well as increases in wages and land prices could harm supply capacity. To control for industrial agglomeration, the number of industrial firms implanted in the state by kilometer-squared is employed.

To measure differences in production factor costs, the average wage of the state is employed. An increase in wages is suppose to deteriorate supply capacity, but average wages can also be an indicator of skilled-labor endowments which can improve supply capacity.

At the end of the 90s, Mexican government attempted to reform the electric sector. According to President Zedillo's Mexico faced a growing demand for electrical power and a chronic insufficiency of public resources to make the necessary investments to satisfy this demand (Breceda, 2000). Indeed, 
Figure 4. Supply capacity growth

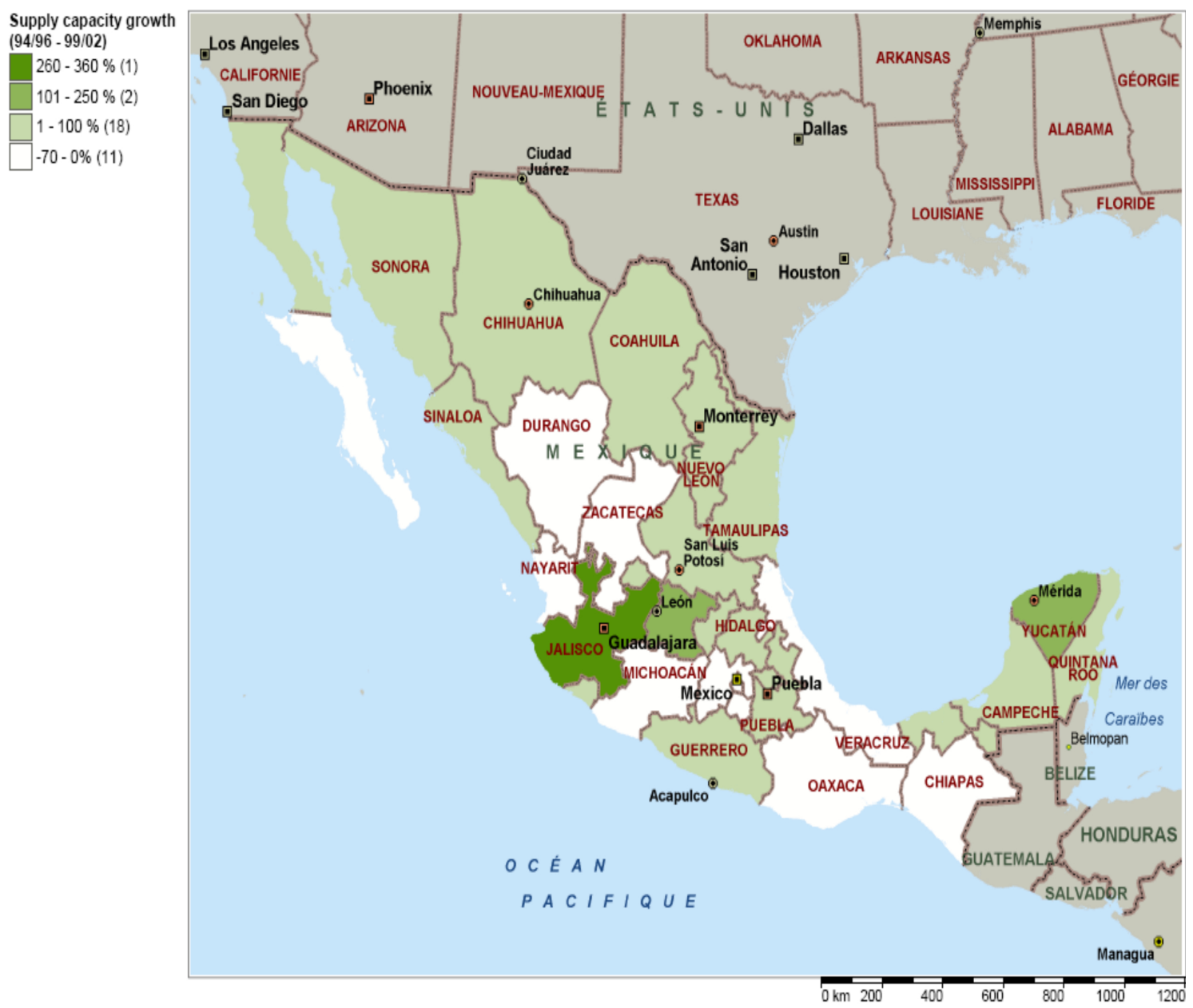

Source: Elaborated by the author.

Table 4. Descriptive statistics

\begin{tabular}{|c|c|c|c|c|c|}
\hline Variable & Obs & Mean & Std. Dev. & Min & Max \\
\hline Exports & 288 & 6.553 & 1.932 & 2.034 & 9.985 \\
\hline Exports/GDP & 288 & -9.277 & 1.923 & -13.681 & -5.955 \\
\hline $\mathrm{GDP}_{t-1}$ & 288 & 10.606 & 0.881 & 8.827 & 13.293 \\
\hline (GDP âĂŞ exports) & 288 & 10.595 & 0.871 & 8.806 & 13.334 \\
\hline Population & 288 & 14.619 & 0.803 & 12.809 & 16.453 \\
\hline Wages & 288 & 2.488 & 0.522 & 1.419 & 3.650 \\
\hline Price of kwh & 288 & -2.815 & 0.531 & -4.059 & -1.765 \\
\hline Agglomeration & 288 & -2.818 & 1.195 & -5.160 & 1.055 \\
\hline Road network & 288 & 8.894 & 0.997 & 5.004 & 10.471 \\
\hline FMP & 288 & -3.597 & 0.980 & -5.015 & 0.302 \\
\hline US GDP/Distance & 288 & 9.191 & 0.945 & 8.012 & 12.893 \\
\hline US imports/Distance & 288 & 7.061 & 0.963 & 5.678 & 10.919 \\
\hline
\end{tabular}

Mexico is a country where the impacts of fluctuations in energy prices, particularly natural gas and electricity, on industrial competitiveness are source of debate. To contribute to this debate, the average cost per Kilowatt for the industries is included as a measure of production costs.

Finally, in addition to foreign market potential values obtained in previous sections, two alternative measures of foreign market potential are employed. The first is the ratio of real US GDP to distance between US and state- $i$; the second is the ratio of US imports from other regions (countries and states) to distance between the US and state- $i$. Table 4 presents the summary statistics and appendix A presents a detailed description and sources of the data.

Before proceeding to estimation, some econometric issues must be addressed. In this type of model, 
the literature usually takes GDP as an endogenous variable. Indeed, by definition, exports are a component of GDP. Three different approaches are employed to handle this. Firstly, one year lagged GDP values are employed as measures of economic size. Secondly, exports are subtracted to GDP, and the result can be interpreted as a type of state level domestic absorption. Finally, following Redding and Venables (2004a), a theoretical restriction that $\beta_{1}=1$ is imposed, and the export-income ratio is employed as the dependent variable.

A most important econometric issue is the influence of neighboring states on export performances. In a similar framework, Koch et al. (2007) employ the properties of destination country price index (see equation 4) to derive an empirical specification involving a spatial autoregressive form in trade flows. More precisely, since the price index is a function of imports from all regions, the exports from one region would be influenced by other regions exports through this index. These authors suggest that the coefficient of the spatial lag dependent variable can be interpreted as a measure of spatial competition. LeSage and Pace (2008) provide two econometrical motivations to include a spatial lag of the dependent variable in the study of trade flows. The first one consist of considering spatial dependence as a long-run equilibrium of a dynamic spatiotemporal process. In other words, a shock in a region is transmitted directly to its neighbors, it is transmitted indirectly to its neighbors neighbors, as well as to its neighbors neighbors neighbors, and so on; moreover, shocks get reflected back to the region from its neighbors. As a consequence, in the equilibrium, the dependent variable in any observation depends on the exogenous variables and error terms in all other observations. The second motivation is founded on an omitted variables argument. These authors show that omitting variables that exhibit a spatial dependence can lead to any: spatial lag model (if the omitted variable is correlated to any exogenous regressor) or spatial error model (if the omitted variable is correlated to the error term).

According to equation 9, factors are immobile across regions and resources are drawn out of non export sectors. However, in the case of regions inside the same country where labour can be a mobile factor, an export sector expansion can draw production resources from other regions via labour migration 2. In addition, improvements in variables such as the road network can lead to improvements in export performances to neighboring regions using this road network to export. Thus, observed and unobserved neighboring characteristics might influence the export performance of a Mexican state- $i$. Following LeSage and Pace (2008) advises, it should be convenient to include a spatial lag of the dependent variable. However, in the presence of spatially dependent omitted variables correlated only with the error terms, the error terms will exhibit some form of cross-sectional correlation that has to be dealt with (Koch et al., 2007). In our case, Mexican states can face to similar unobserved shocks that lead to a cross-sectional correlation of this kind. For example, a slowdown in the demand of the automobile industry would impact states exporting this industry related products. To handle this cross-sectional correlation, we assume that the disturbance term follows a first order spatial autoregressive process. Including both, the spatial autoregressive disturbances and the spatial lag dependent model in the model yields to a mixed-regressive-spatial autoregressive model with spatial autoregressive disturbance, commonly called the General Spatial Model $(\mathrm{SAC})^{3}$ :

$$
\begin{aligned}
X_{i}(t) & =z_{i}(t) \beta+\lambda W_{i} X_{i}(t)+u_{i}(t)=Z_{i}(t) \delta+u_{i}(t), \quad|\lambda|<1 \\
u_{i}(t) & =\rho M_{i} u_{i}(t)+\varepsilon_{i}(t), \quad|\rho|<1
\end{aligned}
$$

where $Z_{i}(t)=\left[z_{i}(t), X_{i}(t)\right] ; \delta=\left[\beta^{\prime}, \lambda\right]^{\prime} ; \lambda$ and $\rho$ are scalar autoregressive parameters; $W_{i}=M_{i}$ are $N \times N$

spatial weighting matrices which defines the interactions between states; and $\varepsilon_{i}(t)$ is an $N \times 1$ vector of the remainder disturbances or innovations (Kapoor et al., 2007) in period $t$ with mean zero and variance $\sigma_{\varepsilon}^{2}$. This assumption implies that a shock in state- $i$ would be transmitted to all other states affecting their export performance. LeSage and Pace (2008) propose to take into account the spatial dependences of both the origin and the destination regions. In our case, given that a common destination for all exports is assumed, spatial dependences are considered only between the exporter regions. The weight matrices $W_{i}=M_{i}$ are constructed as follows. For any year $t=1, \ldots, T$, a weight matrix $W_{i}$ is defined as:

$$
W_{i}(t)=\left[\begin{array}{ccc}
0 & w_{i, j} & w_{i, k} \\
w_{j, i} & 0 & w_{i, k} \\
w_{k, i} & w_{i, k} & 0
\end{array}\right]
$$

\footnotetext{
${ }^{2}$ Note that if this is the case, the coefficient value of $M P_{i}$ may be higher than one.

${ }^{3}$ Kelejian and Prucha (1998) refer to the SAC model as the (first-order) spatial autoregressive model with (first-order) autoregressive disturbances of order $(1,1)$, for short $\operatorname{SARAR}(1,1)$.
} 
where $w_{i, j}=\left(1 /\right.$ distance $\left._{i, j}\right)$ if the states $i$ and $j$ are neighbors, and zero otherwise. Matrix $W_{t}$ is standardized, so that the sum of every row of the matrix is one.

An additional econometric problem comes from the construction of the foreign market potential. This variable was calculated for three year periods, while this section employs yearly data. In addition, firm heterogeneity literature suggests that the heterogeneity in productivity of existing firms plays an important role in the export performance. Chaney (2008) extends Melitz (2003) model to a multicountry framework. He shows that the number of firms exporting, as well as its export levels, depend on firms' productivity and on the elasticity of substitution. When trade barrier decreases, a region hosting competitive firms captures a larger market share than a region hosting less productive firms. The firms already implanted in a region influence both present and future export performance of the region. These points suggest that there are characteristics that are transmitted over time. To take this into account, it is allowed for the innovations to be correlated over time. Following Kapoor et al. (2007), the error structure is defined as:

$$
\varepsilon_{i}(t)=\mu_{i}+v_{i}(t)
$$

where $\mu_{i}$ represents the $N \times 1$ vector of state- $i$ specific error components with zero mean and variance $\sigma_{\mu}^{2}$;

and $v_{i}(t)$ in an $N \times 1$ of error components with zero mean and variance $\sigma_{v}^{2}$ that vary over both $t$ periods and $i$ states. The innovations vector $\varepsilon_{i}(t)$ thus depends on disturbances which differ for each state but are constant for the same state over different years $\left(\mu_{i}\right)$, and of disturbances that are specific to each state and to each time period $\left(v_{i}(t)\right)$. In other words, the specification of the innovations corresponds to that of a classical one-way error component model (Kapoor et al., 2007). It is assumed that the processes $\mu_{i}$ and $v_{i}(t)$ are independent. Thus, $\varepsilon_{i}(t)$ are autocorrelated over time, but are not correlated across units:

$$
E \varepsilon_{i}(t)=0 \text { and } E \varepsilon_{i}(t), \varepsilon_{j}(s)=\left[\begin{array}{cc}
\sigma_{\mu}^{2}+\sigma_{v}^{2} & \text { if } i=j ; t=s \\
\sigma_{\mu}^{2} & \text { if } i=j ; t \neq s \\
0 & \text { otherwise }
\end{array}\right]
$$

Stacking the observations in equations 10,11 and 14 we obtain:

$$
\begin{gathered}
X=Z \delta+u \\
u=\rho\left(I_{T} \otimes W\right) u+\varepsilon=\left(I_{N T}-\rho I_{T} \otimes W\right)^{-1} \varepsilon \\
\varepsilon=\left(e_{T} \otimes I_{N}\right) \mu+v
\end{gathered}
$$

where $X=\left[X^{\prime}(1), \ldots, X^{\prime}(T)\right]^{\prime} ; Z=\left[Z^{\prime}(1), \ldots, Z^{\prime}(T)\right]^{\prime} ; u=\left[u^{\prime}(1), \ldots, u^{\prime}(T)\right]^{\prime} ; \varepsilon=\left[\varepsilon^{\prime}(1), \ldots, \varepsilon^{\prime}(T)\right]^{\prime} ; v=$ $\left[v^{\prime}(1), \ldots, v^{\prime}(T)\right]^{\prime} ; \mu=\left[\mu^{\prime}(1), \ldots, \mu^{\prime}(T)\right]^{\prime} ; I_{T}, I_{N}$ and $I_{N T}$ are identity matrices of dimension $T, N$ and $N T$, respectively; $e_{T}$ is a vector of ones of dimension $T$; and $\otimes$ denotes the Kronecker product. Note that this specification allows for spatial interactions in both the error components $v_{i}(t)$ and the specific error $\mu_{i}$ components. Finally, the variance-covariance matrix of the disturbance vector $\varepsilon$ can be represented as:

$$
\Omega_{\varepsilon}=E\left(\varepsilon \varepsilon^{\prime}\right)=\sigma_{\mu}^{2}\left(J_{T} \otimes I_{N}\right)+\sigma_{v}^{2} I_{N T}=\sigma_{v}^{2} Q_{0}+\sigma_{1}^{2} Q_{1}
$$

where $\sigma_{1}^{2}=\sigma_{\mu}^{2} Q_{0}+T \sigma_{v}^{2} ; Q_{0}=\left(I_{T}-\frac{J_{T}}{T}\right) \otimes I_{N} ; Q_{1}=\frac{J_{T}}{T} \otimes I_{N} ;$ and $J_{T}=e_{T} e_{T}^{\prime}$ is a $T \times T$ matrix of unit elements ${ }^{4}$.

The estimation approach employed in this paper is a feasible generalized spatial two stages least squares (FG2SLS) procedure developed by Kapoor et al. (2007) and Kelejian and Prucha (1998). This approach involves three steps. In the first step, the regression model in equation 15 is estimated by two stage least squares (2SLS) to obtain the residuals $(\widehat{u}=X-Z \widehat{\beta})$. In this step, following Kelejian and Prucha (1998), the exogenous regressors and their first and second order spatial lags $\left(z_{i}(t), W_{i} z_{i}(t), W_{i}^{2} z_{i}(t)\right)$ are employed as instruments for the spatial lag of the dependent variable. In the second step, the residuals are used in the generalized moments procedure suggested by Kapoor et al. (2007) to estimate the spatial autoregressive parameter $\widehat{\rho}, \widehat{\sigma}_{\mu}^{2}, \widehat{\sigma}_{v}^{2}$ and $\widehat{\Omega}_{\varepsilon}$ by a non-linear optimization routine. Finally, in the third

\footnotetext{
${ }^{4}$ For more details on the properties of the matrices and assumptions see Kapoor et al. (2007).
} 
step, a spatial Cochrane-Orcutt type transformation of the model is applied to obtain spatially independent disturbances, and this model is reestimated in terms of a feasible generalized spatial least squares estimator. More specifically, multiplying of equations 15 and 16 with $\left(I_{N T}-\widehat{\rho} I_{T} \otimes W\right)$ yields:

$$
X^{*}=Z^{*} \delta+\varepsilon
$$

where $X^{*}=\left[I_{T} \otimes\left(I_{N}-\widehat{\rho} W\right)\right] X$; and $Z^{*}=\left[I_{T} \otimes\left(I_{N}-\widehat{\rho} W\right)\right] Z$. Then the FG2SLS estimator is defined as:

$$
\beta_{F G 2 S L S}=\left(Z^{* \prime} \widehat{\Omega}_{\varepsilon}^{-1} Z^{*}\right)^{-1} Z^{* \prime} \widehat{\Omega}_{\varepsilon}^{-1} X^{*}
$$

\subsection{Estimation results}

Table 5 presents parameter estimates of the model employing OLS which will be used as a benchmark. Note that, to capture Mexican economy volatility (especially during the financial crisis years), time dummies were included to the specification, but not reported. OLS estimates suggest that the size and the foreign market potential are important factors influencing export performances, since both variables are always significantly positively related to the different specifications of the dependent variable. Results suggest that road network is an important factor, since it is significant for the different specifications. When the dependent variable is the total exports (columns 1-2), time lagged GDP, market potential and infrastructure are significantly positively correlated to exports. More importantly, when adding regionally fixed effects to control for spatial heterogeneity, they remain significant; see column 2 in comparison to column 1 . This is not the case for the agglomeration and electricity costs variables which lose their significativity when adding region dummies. When employing domestic absorption as a measure of economic size (columns 3-4), this variable is significant and positively correlated to exports, as well as market potential and road network. Agglomeration variable lost again its significativity when adding region dummies. In the third specification (columns 5-6), the market potential and the road network coefficients are again positive and significant. Given that the only measure of size is the population levels, this variable becomes significant and positively correlated to exports. In this specification, wages become significant and positively correlated to exports/GDP ratio. This result is not robust compared to those found in previous specifications, which suggest that wages coefficient could be influenced by omitted variables bias.

Table 5 also reports the Lagrange multiplier (LM) and its robust versions (RLM) to see which specification applies better to our case, spatial-error or spatial-lag dependences. We can see that we cannot reject the presence of both spatial lag dependent variable and spatial error influences. The next step is then to control for these types of spatial autocorrelation by computing the FG2SLS estimates.

Results (reported in Table 6) suggest that state's size, road infrastructure and foreign market potential are the main determinants of export performance. The size of the state is again significant when measured as economic size. Moreover, when omitting economic size variables, the population size reflects the significance of the size of the states. Concerning spatial dependences, results suggest the presence of these dependences across neighboring states. The spatial lag of the dependent variable is always positive and significant, which suggest the agglomeration of export activity into a group of states. This result can also be interpreted as the result of a positive influence of variables affecting export performance in neighboring regions such as neighbors size and road networks.

The estimate of the autoregressive parameter $\rho$ is always significantly related to the dependent variables, but its sign changes when including regional dummies. We can then infer that this coefficient captures the effects of omitted variables that create both positive and negative spatial spillovers across Mexican states. Hence, controlling for spatial error dependence allows us to reduce the bias created by the omission of important variables. This can be seen clearly if we compare the coefficients of the wages variable reported in column 6 in both Table 5 and Table 6 . Indeed, introducing the error variable spatial wage loses its significance.

The results reported in Table 6 are in line with the theoretical model and can be interpreted as follows. Road density facilitates transportation, thus reducing trade costs improves the export performance. In addition, as suggested by the theory, the expansion of the export sector needs production factors. Thus, the availability of a significant quantity of production factors, measured by the size of the state, would improve the export sector. In addition, improvements in the export sector would be transmitted to neighboring states, creating regions that concentrate the export activity. Finally, after controlling for supply capacity, the foreign market potential is a key element in improving exports. Moreover, the FMP 
Table 5. OLS - Determinants of export performance

\begin{tabular}{|c|c|c|c|c|c|c|}
\hline \multirow[t]{2}{*}{ Dependent variable: } & \multicolumn{4}{|c|}{ Exports } & \multicolumn{2}{|c|}{ Exports / GDP } \\
\hline & $(1)$ & $(2)$ & (3) & (4) & $(5)$ & (6) \\
\hline$\overline{G D P}_{t-1}$ & $\begin{array}{r}1.363 \\
(0.236)^{* *}\end{array}$ & $\begin{array}{r}1.715 \\
(0.262)^{* *}\end{array}$ & & & & \\
\hline (GDP âĂŞ exports) & & & $\begin{array}{r}1.200 \\
(0.236)^{* *}\end{array}$ & $\begin{array}{r}1.440 \\
(0.277)^{* *}\end{array}$ & & \\
\hline Population & $\begin{array}{r}-0.613 \\
(0.243)^{*}\end{array}$ & $\begin{array}{r}-0.682 \\
(0.289)^{*}\end{array}$ & $\begin{array}{r}-0.472 \\
(0.242)\end{array}$ & $\begin{array}{r}-0.398 \\
(0.304)\end{array}$ & $\begin{array}{r}0.523 \\
(0.092)^{* *}\end{array}$ & $\begin{array}{r}1.052 \\
(0.088)^{* *}\end{array}$ \\
\hline Wages & $\begin{array}{r}0.283 \\
(0.585)\end{array}$ & $\begin{array}{r}-1.047 \\
(0.538)\end{array}$ & $\begin{array}{r}0.606 \\
(0.582)\end{array}$ & $\begin{array}{r}-0.639 \\
(0.557)\end{array}$ & $\begin{array}{r}2.701 \\
(0.460)^{* *}\end{array}$ & $\begin{array}{r}1.331 \\
(0.523)^{*}\end{array}$ \\
\hline Price of kwh & $\begin{array}{r}-0.862 \\
(0.389)^{*}\end{array}$ & $\begin{array}{r}-0.173 \\
(0.308)\end{array}$ & $\begin{array}{r}-0.776 \\
(0.399)\end{array}$ & $\begin{array}{r}-0.108 \\
(0.311)\end{array}$ & $\begin{array}{r}-0.189 \\
(0.410)\end{array}$ & $\begin{array}{r}0.093 \\
(0.352)\end{array}$ \\
\hline Agglomeration & $\begin{array}{r}0.618 \\
(0.067) * *\end{array}$ & $\begin{array}{r}0.176 \\
(0.098)\end{array}$ & $\begin{array}{r}0.613 \\
(0.069)^{* *}\end{array}$ & $\begin{array}{r}0.157 \\
(0.101)\end{array}$ & $\begin{array}{r}0.603 \\
(0.081)^{* *}\end{array}$ & $\begin{array}{r}0.113 \\
(0.105)\end{array}$ \\
\hline Road network & $\begin{array}{r}0.654 \\
(0.069)^{* *}\end{array}$ & $\begin{array}{r}0.575 \\
(0.092)^{* *}\end{array}$ & $\begin{array}{r}0.655 \\
(0.072)^{* *}\end{array}$ & $\begin{array}{r}0.543 \\
(0.100)^{* *}\end{array}$ & $\begin{array}{r}0.599 \\
(0.084)^{* *}\end{array}$ & $\begin{array}{r}0.295 \\
(0.099)^{* *}\end{array}$ \\
\hline FMP & $\begin{array}{r}0.846 \\
(0.089)^{* *}\end{array}$ & $\begin{array}{r}0.592 \\
(0.051)^{* *}\end{array}$ & $\begin{array}{r}0.921 \\
(0.086)^{* *}\end{array}$ & $\begin{array}{r}0.671 \\
(0.054)^{* *}\end{array}$ & $\begin{array}{r}1.051 \\
(0.090)^{* *}\end{array}$ & $\begin{array}{r}0.728 \\
(0.075)^{* *}\end{array}$ \\
\hline Observations & 288 & 288 & 288 & 288 & 288 & 288 \\
\hline R-squared & 0.79 & 0.87 & 0.79 & 0.86 & 0.76 & 0.84 \\
\hline Time dummies & yes & yes & yes & yes & yes & yes \\
\hline $\begin{array}{l}\text { Region dummy } \\
\text { Diagnostics for spo }\end{array}$ & $\begin{array}{r}\text { no } \\
\text { ependence }\end{array}$ & yes & no & yes & no & yes \\
\hline $\mathrm{LM}_{E R R}$ & $8.98^{* *}$ & $30.44^{* *}$ & $9.79^{* *}$ & $28.39^{* *}$ & $5.11^{*}$ & $19.61^{* *}$ \\
\hline $\mathrm{RLM}_{E R R}$ & $32.05^{* *}$ & $23.88^{* *}$ & $32.61^{* *}$ & $22.74^{* *}$ & $12.43^{* *}$ & $20.35^{* *}$ \\
\hline $\mathrm{LM}_{L A G}$ & $4.60 *$ & $9.21^{* *}$ & $3.80^{*}$ & $8.48^{* *}$ & 0.59 & $3.86 *$ \\
\hline $\operatorname{RLM}_{L A G}$ & $27.64^{* *}$ & 2.65 & $26.61^{* *}$ & 2.83 & $7.91^{* *}$ & $4.59 *$ \\
\hline
\end{tabular}

Table 6. FGLS - Determinants of export performance

\begin{tabular}{|c|c|c|c|c|c|c|}
\hline \multirow[t]{2}{*}{ Dependent variable: } & \multicolumn{4}{|c|}{ Exports } & \multicolumn{2}{|c|}{ Exports / GDP } \\
\hline & $(1)$ & $(2)$ & (3) & $(4)$ & $(5)$ & (6) \\
\hline$\overline{G D P}_{t-1}$ & $\begin{array}{r}1.355 \\
(0.275)^{* *}\end{array}$ & $\begin{array}{r}1.323 \\
(0.368)^{* *}\end{array}$ & & & & \\
\hline (GDP âĂŞ exports) & & & $\begin{array}{r}0.998 \\
(0.264)^{* *}\end{array}$ & $\begin{array}{r}0.790 \\
(0.344)^{*}\end{array}$ & & \\
\hline Population & $\begin{array}{r}-0.390 \\
(0.313)\end{array}$ & $\begin{array}{r}0.035 \\
(0.393)\end{array}$ & $\begin{array}{r}-0.091 \\
(0.309)\end{array}$ & $\begin{array}{r}0.548 \\
(0.377)\end{array}$ & $\begin{array}{r}0.698 \\
(0.239) * *\end{array}$ & $\begin{array}{r}1.276 \\
(0.227)^{* *}\end{array}$ \\
\hline Wages & $\begin{array}{r}0.257 \\
(0.629)\end{array}$ & $\begin{array}{r}-0.493 \\
(0.687)\end{array}$ & $\begin{array}{r}0.828 \\
(0.621)\end{array}$ & $\begin{array}{l}-0.001 \\
(0.669)\end{array}$ & $\begin{array}{r}1.217 \\
(0.675)\end{array}$ & $\begin{array}{r}0.596 \\
(0.693)\end{array}$ \\
\hline Price of kwh & $\begin{array}{r}-0.006 \\
(0.382)\end{array}$ & $\begin{array}{r}0.151 \\
(0.401)\end{array}$ & $\begin{array}{l}-0.004 \\
(0.402)\end{array}$ & $\begin{array}{r}0.133 \\
(0.421)\end{array}$ & $\begin{array}{r}-0.030 \\
(0.407)\end{array}$ & $\begin{array}{r}-0.021 \\
(0.384)\end{array}$ \\
\hline Agglomeration & $\begin{array}{r}0.231 \\
(0.164)\end{array}$ & $\begin{array}{r}0.016 \\
(0.195)\end{array}$ & $\begin{array}{r}0.243 \\
(0.166)\end{array}$ & $\begin{array}{r}0.038 \\
(0.195)\end{array}$ & $\begin{array}{r}0.332 \\
(0.181)\end{array}$ & $\begin{array}{r}0.091 \\
(0.213)\end{array}$ \\
\hline Road network & $\begin{array}{r}0.390 \\
(0.128)^{* *}\end{array}$ & $\begin{array}{r}0.411 \\
(0.135)^{* *}\end{array}$ & $\begin{array}{r}0.378 \\
(0.129)^{* *}\end{array}$ & $\begin{array}{r}0.391 \\
(0.139)^{* *}\end{array}$ & $\begin{array}{r}0.345 \\
(0.132)^{* *}\end{array}$ & $\begin{array}{r}0.331 \\
(0.133)^{*}\end{array}$ \\
\hline FMP & $\begin{array}{r}0.663 \\
(0.134)^{* *}\end{array}$ & $\begin{array}{r}0.527 \\
(0.138)^{* *}\end{array}$ & $\begin{array}{r}0.789 \\
(0.138)^{* *}\end{array}$ & $\begin{array}{r}0.591 \\
(0.153)^{* *}\end{array}$ & $\begin{array}{r}0.951 \\
(0.141)^{* *}\end{array}$ & $\begin{array}{r}0.639 \\
(0.143)^{* *}\end{array}$ \\
\hline W Exports & $\begin{array}{r}0.513 \\
(0.121)^{* *}\end{array}$ & $\begin{array}{r}0.381 \\
(0.187)^{*}\end{array}$ & $\begin{array}{r}0.463 \\
(0.123)^{* *}\end{array}$ & $\begin{array}{r}0.397 \\
(0.198)^{*}\end{array}$ & $\begin{array}{r}0.451 \\
(0.133)^{* *}\end{array}$ & $\begin{array}{r}0.562 \\
(0.179)^{* *}\end{array}$ \\
\hline Rho & $\begin{array}{r}-0.336 \\
(0.090)^{* *}\end{array}$ & $\begin{array}{r}0.077 \\
(0.010)^{* *}\end{array}$ & $\begin{array}{r}-0.309 \\
(0.071)^{* *}\end{array}$ & $\begin{array}{r}0.071 \\
(0.012)^{* *}\end{array}$ & $\begin{array}{r}-0.351 \\
(0.048)^{* *}\end{array}$ & $\begin{array}{r}-0.276 \\
(0.028)^{* *}\end{array}$ \\
\hline Observations & 288 & 288 & 288 & 288 & 288 & 288 \\
\hline R-squared & 0.76 & 0.62 & 0.74 & 0.61 & 0.67 & 0.67 \\
\hline Time dummy & yes & yes & yes & yes & yes & yes \\
\hline Region dummy & no & yes & no & yes & no & yes \\
\hline
\end{tabular}

estimator is lower than one, which suggests that an increase in the demand side raises costs and prices in the export sector, discouraging supply capacity as proposed by Redding and Venables (2004a).

Given that the FMP variable was constructed from regressions involving export data, one could doubt the pertinence of employing this variable. This variable is replaced, therefore, by two alternative 
Table 7. Regressions with alternative measures of FMP

\begin{tabular}{|c|c|c|c|c|c|c|}
\hline \multirow[t]{2}{*}{ Dependent variable: } & \multicolumn{4}{|c|}{ Exports } & \multicolumn{2}{|c|}{ Exports / GDP } \\
\hline & (1) & (2) & (3) & (4) & (5) & (6) \\
\hline \multirow[t]{2}{*}{$\overline{\mathrm{GDP}}_{t-1}$} & 1.306 & 1.305 & & & & \\
\hline & $(0.370)^{* *}$ & $(0.370)^{* *}$ & & & & \\
\hline \multirow[t]{2}{*}{ (GDP âĂŞ exports) } & & & 0.782 & 0.781 & & \\
\hline & & & $(0.345)^{*}$ & $(0.345)^{*}$ & & \\
\hline \multirow[t]{2}{*}{ Population } & 0.047 & 0.048 & 0.554 & 0.555 & 1.268 & 1.267 \\
\hline & $(0.395)$ & $(0.395)$ & $(0.378)$ & $(0.378)$ & $(0.228)^{* *}$ & $(0.228)^{* *}$ \\
\hline \multirow[t]{2}{*}{ Wages } & -0.538 & -0.540 & -0.073 & -0.075 & 0.507 & 0.503 \\
\hline & $(0.686)$ & $(0.686)$ & $(0.669)$ & $(0.668)$ & $(0.692)$ & $(0.691)$ \\
\hline \multirow[t]{2}{*}{ Price of kwh } & 0.174 & 0.175 & 0.161 & 0.161 & 0.003 & 0.004 \\
\hline & $(0.402)$ & $(0.402)$ & $(0.423)$ & $(0.423)$ & $(0.385)$ & $(0.385)$ \\
\hline \multirow[t]{2}{*}{ Agglomeration } & 0.014 & 0.014 & 0.034 & 0.034 & 0.089 & 0.088 \\
\hline & $(0.196)$ & $(0.196)$ & $(0.195)$ & $(0.195)$ & $(0.213)$ & $(0.213)$ \\
\hline \multirow[t]{2}{*}{ Road network } & 0.413 & 0.413 & 0.393 & 0.393 & 0.338 & 0.338 \\
\hline & $(0.135)^{* *}$ & $(0.135)^{* *}$ & $(0.139)^{* *}$ & $(0.139)^{* *}$ & $(0.133)^{*}$ & $(0.133)^{*}$ \\
\hline \multirow[t]{2}{*}{ US GDP/Distance } & 0.552 & & 0.625 & & 0.673 & \\
\hline & $(0.134)^{* *}$ & & $(0.146)^{* *}$ & & $(0.138)^{* *}$ & \\
\hline \multirow[t]{2}{*}{ US imports/Distance } & & 0.555 & & 0.628 & & 0.676 \\
\hline & & $(0.134)^{* *}$ & & $(0.146)^{* *}$ & & $(0.138)^{* *}$ \\
\hline \multirow[t]{2}{*}{ W Exports } & 0.389 & 0.390 & 0.415 & 0.417 & 0.576 & 0.577 \\
\hline & $(0.186)^{*}$ & $(0.186)^{*}$ & $(0.196)^{*}$ & $(0.195) *$ & $(0.177)^{* *}$ & $(0.176)^{* *}$ \\
\hline \multirow[t]{2}{*}{ Rho } & 0.081 & 0.081 & 0.073 & 0.073 & -0.272 & -0.273 \\
\hline & $(0.010)^{* *}$ & $(0.010)^{* *}$ & $(0.012)^{* *}$ & $(0.012)^{* *}$ & $(0.027)^{* *}$ & $(0.027)^{* *}$ \\
\hline Observations & 288 & 288 & 288 & 288288 & 288 & \\
\hline R-squared & 0.62 & 0.62 & 0.61 & 0.61 & 0.67 & 0.67 \\
\hline Time dummies & yes & yes & yes & yes & yes & yes \\
\hline Region dummy & yes & yes & yes & yes & yes & yes \\
\hline
\end{tabular}

measures of market potential. From gravity equation we have found a distance estimator around minus one. The first alternative measure is then the ratio of real US GDP to distance between US and state- $i$; the second is the ratio of total US imports minus state- $i$ exports to distance between the US and state- $i$.

Table 7 draws the estimates when employing alternative measures of market potential. Comparing results to those found previously, we can see that there are no significant differences on the significance and coefficient values for the market potential, road network and size variables. Indeed, these remain the most important factors explaining export performances. Population size is also significant excluding when the GDP and the absorption variables are excluded. Regarding the coefficient value of the three market potential variables, in all cases are lower than one as expected. Moreover, except for the population variables, after controlling for spatial dependences ${ }^{5}$, their coefficient value become smaller. Hence, not controlling for these dependences could lead to overstate the importance of significant variables, and even to give significance to variables that are not (as the variable wages in our case ${ }^{6}$ ).

Finally, note that, except for production costs which are not significant, results are in line with equation 9. In other words, states' size, improvements in internal trade costs, and foreign market potential are the main determinants for export supply capacity.

\section{Conclusions}

This paper studies the export performance of Mexican states after liberalization reforms. The paper focuses on the role played by the transport costs determining access to foreign markets, as well as the states' competitiveness in supplying foreign market demand. Given the Mexico's location, its main foreign market in recent years has been the US market. Thus, the theoretical assumption is that Mexican exports vary in function of shifts in the US demand for tradable goods. The paper also studies the response of the different states to these changes in demand in order to determine which states profit better from liberalization reforms.

\footnotetext{
${ }^{5}$ The results without spatial lag variable and spatial error not reported for the alternative measures of FMP, but available under request.

${ }^{6}$ The wages variable has a similar behavior when using alternative measures of FMP. Indeed, this variable is significantly positively related to the exports/GDP variable until controlling for spatial dependences.
} 
Results also highlight the importance of states' market potential in determining export levels. Northern border regions have almost five times more market potential than southern regions. However, when analyzing the changes in market potential and their impact on export performance, northern border states fare no better. Furthermore, results suggest that the states that have the better export performance are not necessarily those with the higher increase in market potential. An important factor in export performance is the supply capacity improvement of each state. States that experience an increase in supply capacity are, in most cases, also the states with better export performance.

Among the factors influencing supply capacity, results indicate that economic size, road infrastructure and spatial spillovers from neighboring states' are significant factors. Since export sector expansion needs additional resources, better endowed states react better to this expansion. Improvements in infrastructure impact directly the trade costs since it makes easier the distribution of goods and supplies. Concerning spatial dependences, result suggest the presence of positive spatial spillovers from neighboring states' export activity. In other words, changes in a state's export volume or in state's characteristics influencing export activity (as size and road network) will indirectly have a positive impact on the supply capacity in neighboring states. According to obtained results, there are also spatial spillovers through the error term. This result implies that state level data cannot be considered as independently generated because of the presence of similarities with neighboring states. Moreover, taking into account this form of dependence allows to reduce the omitted bias variables. Results also suggest that differences in production costs, measured by the wages and electricity prices, as well as their evolution have not affected the competitiveness of export activities.

Unfortunately for the Mexican economy, results suggest that in most cases export improvement is due mainly to an increase in the US demand for tradable goods rather than to an improvement in supply capacity. It seems, then, that an export-led growth strategy has reinforced Mexico's dependency on the US economy. As a consequence, Mexico's exports have become vulnerable to slowdowns in the United States. Thus, citing Blecker (2006), "... given the likelihood that the United States will have slower growth over the next several years as a result of its mammoth fiscal and trade deficits, it is all the more important for Mexico to redouble its efforts at export diversification (perhaps more through marketing efforts rather than trade agreements)." (Blecker, 2006: pp.33-34). In addition, it is clear that there are some regions for which the US demand (measured as the market potential) is not as important as for other regions. Hence, in order to reduce disparities across regions, Mexican economic policy must also look to stimulating national demand (especially in the poorest states), rather than expecting improvements in a foreign demand that only favours a group of states.

\section{References}

[1] Blecker, R.A. 2006 "Macroeconomic and Structural Constraints on Export-Led Growth in Mexico." American University Department of Economics, Working Paper Series 2006-05.

[2] Breceda, M. 2000 "Debate on reform of the electricity sector in Mexico: Report on its Background, Current Status and Outlook." North American Commission for Environmental Cooperation, Canada.

[3] Borraz F. and E. López-Córdova, 2004. "Has Globalization Deepened Income Inequality in Mexico?" Inter-American Development Bank, Mimeo.

[4] Chaney, T., 2008. "Distorted Gravity: The Intensive and Extensive Margins of International Trade." American Economic Review 98(4): 1707-21.

[5] Disdier A.C. and K. Head, 2003. "Exaggerated reports on the death of distance: lessons from a meta-analysis." University of British Columbia, mimeo.

[6] Fujita, M., P. Krugman and A. Venables, 1999. The spatial economy. Cities, regions and international trade. Cambridge, MIT Press.

[7] Galindo, L. M., and J. Ros, 2008. "Alternatives to inflation targeting in Mexico." International Review of Applied Economics, 22(2): 201-214.

[8] Hanson G.H., 1998. "Regional adjustment to trade liberalization." Regional Science and Urban Economics 28: 419-444.

[9] Head, K. and T. Mayer, 2002. "Illusory Border Effects: Distance Mismeasurement Inflates Estimates of Home Bias in Trade." CEPII Working Paper No. 2002 - 01. 
[10] Head, K. and T. Mayer, 2004. "Market Potential and the Location of Japanese Investment in the European Union." Review of Economics and Statistics 86(4): 959-972.

[11] Kapoor, M., H. H. Kelejian and I. R. Prucha, 2007. "Panel data models with spatially correlated error components." Journal of Econometrics 140: 97-130.

[12] Kelejian, H.H. and I.R. Prucha, 1998. "A generalized spatial least squares procedure for estimating a spatial autoregressive model with autoregresssive disturbances." Journal of Real Estate Finance and Economics, 17, 99-121.

[13] Kelejian, H.H. and Prucha, I.R., 2004. "Estimation of Simultaneous Systems of Spatially Interrelated Cross Sectional Equations." Journal of Econometrics, 118: 27-50.

[14] Koch, W., C. Ertur and K. Behrens, 2007."Dual gravity : Using spatial econometrics to control for multilateral resistance." LEG - Document de travail - Economie 2007-03, LEG, Laboratoire d'Economie et de Gestion, CNRS UMR 5118, Université de Bourgogne.

[15] Krugman, P. and R. L. Elizondo, 1996."Trade policy and the Third World metropolis." Journal of Development Economics 49(1): 137-150.

[16] LeSage, J.P. and R.K. Pace, 2008. "Spatial Econometric Modeling Of Origin-Destination Flows." Journal of Regional Science 48(5): 941-967.

[17] Martin, P. and C.A. Rogers,1995. "Industrial location and public infrastructure." Journal of International Economics 39: 335-351.

[18] Mayer T., 2008. "Market Potential and Development." CEPR Discussion Paper 6798.

[19] Mayer, T. and S. Zignago, 2005. "Market Access in Global and Regional Trade." CEPII Working Papers 2005-02.

[20] Melitz, M., 2003, "The Impact of Trade on Aggregate Industry Productivity and Intra-Industry Reallocations," Econometrica, 71 (6): 1695-1725.

[21] Moreno-Brid J.C., J.C. Rivas-Valvidia and J. Santamaría, 2005. "Mexico: Economic growth exports and industrial performance alter NAFTA." CEPAL, Serie: Estudios y perspectivas 42.

[22] Pacheco-López, P. and A. P. Thirlwall, 2004. "Trade liberalisation in Mexico: Rhetoric and reality." Banca Nazionale del Lavoro Quarterly Review, 229: 141-167.

[23] Redding S. and A.J. Venables, 2004a. "Geography and Export Performance: External Market Access and Internal Supply Capacity." In: Baldwin R, Winters LA (eds) Challenges to Globalization: Analyzing the Economics. CEPR-NBER conference volume, NBER and Chicago University Press.

[24] Redding S. and A.J. Venables, 2004b. "Economic Geography and International Inequality." Journal of International Economics, 62(1): 53-82. 


\section{A Variables definition and data sources}

\section{A.1 Preliminary notes.}

All variables are introduced in logarithmic transformation. Variables indicated by $(*)$ concern data reported in Mexican pesos. This data was transformed to 1996 constant USD employing the real exchange rate Mexico Peso / US Dollar reported by the Centro de Estudios de las Finanzas Públicas de la H. Cámara de Diputados.

\section{A.2 Gravity equation}

\section{A.2.1 Sample}

The sample is composed by the following economies for the 1994-2002 period :

1. 32 Mexico's federative entities: Aguascalientes (AGS), Baja California (BCN), Baja California South (BCS), Campeche (CAM), Coahuila (COA), Colima (COL), Chiapas (CHS), Chihuahua (CHI), the Federal District (DF), Durango (DGO), Guanajuato (GTO), Guerrero (GRO), Hidalgo (HGO), Jalisco (JAL), Mexico (MEX), Michoacan (MIC), Morelos (MOR), Nayarit (NAY), Nuevo Leon (NLN), Oaxaca (OAX), Puebla (PUE), Queretaro (QRO), Quintana Roo (QTR), San Luis Potosi (SLP), Sinaloa (SIN), Sonora (SON), Tabasco (TAB), Tamaulipas (TAM), Tlaxcala (TLA), Veracruz (VER), Yucatan (YUC), and Zacatecas (ZAC).

2. OECD member countries at 1994: Australia (AUS), Austria (AUT), Belgium (BEL), Canada $(\mathrm{CAN})$, Switzerland (CHE), Germany (DEU), Spain (ESP), Finland (FIN), France (FRA), United Kingdom (GBR), Greece (GRC), Iceland (ISL), Italy (ITA), Japan (JPN), Netherlands (NLD), Norway (NOR), New Zealand (NZL), Portugal (PRT), Sweden (SWE), Turkey (TUR), United States (USA).

3. United States main trade partners (in the top ten) not belonging to the OECD at 1994: China (CHN), Republic of Korea (KOR), Taiwan (TWN).

\section{A.2.2 Dependent variable}

Exports. Manufacturing trade flows. Data source: Data on bilateral trade of OECD and main US partners comes from CEPII Trade, Production and Bilateral Protection Database [Mayer and Zignago (2005)]. Mexican export data was obtained from Borraz and López-Córdova (2004).

\section{A.2.3 Explanatory variables}

Distance. Population weighted distance, following Head and Mayer (2002) formula: distance $_{i, u s}=$ $\sum_{j \in i} \frac{\text { population }_{j}}{\text { population }_{i}}$ distance $_{j, u s}$. Distance between countries is measured as the great circle distance between the 25 most important agglomerations. Data source: CEPII distances database. Distance between Mexican states and US is the weighted road distance from the state's most important urban agglomerations (those over 150000 inhabitants) to the nearest border crossing. Data source: Constructed by the author with population data from the 1990 population census data (INEGI) and road distance data from the Mexican Secretaría de Comunicaciones y Transportes (SCT).

Common border. Binary variable that takes the value of 1 if countries share a common border and 0 otherwise. Since this variable is at country level, this variable takes the value of 1 for all Mexican states - US common border.

\section{A.3 The determinants of supply capacity}

\section{A.3.1 Sample}

The sample is composed by the 32 Mexico's federative entities for the 1994-2002 period. 


\section{A.3.2 Dependent variable}

Exports. Manufacturing trade flows. Data source: Borraz and López-Córdova (2004).

\section{A.3.3 Explanatory variables}

GDP $_{t-1}$. (*) Time lag of State gross domestic product. Data source: INEGI.

Population. State total population. Data source: Consejo Nacional de Población (CONAPO).

Wages. (*) Average daily wage reported to the social security in 2000 constant USD. Data source: Secretaría del Trabajo y Previsión Social (STPS).

Price of kwh. (*) Price of kilowatt hour for industrial activity. Data source: Comisión Féderal de Electricidad (CFE).

Agglomeration. Ratio of industrial sector consumers of electricity to state's area. Data source: Comisión Féderal de Electricidad (CFE).

Road network. Ratio of squared kilometers of paved roads to state's area. Data source: INEGI

US GDP. Real GDP in 1996 dollars. Data source: Bureau of Economic Analysis (BEA).

US imports. US total imports. Data source: US International Trade Commission database.

Regional dummies are created grouping states in 10 regions: (1) Northwest: Baja California, Baja California South, Sonora and Sinaloa; (2) North: Chihuahua, Durango and Zacatecas; (3) Northeast: Coahuila, Nuevo Leon and Tamaulipas; (4) Occident: Colima, Jalisco, Michoacan and Nayarit; (5) Central: Aguascalientes; Guanajuato, San Luis Potosi and Queretaro; (6) Metropolitan: Federal District, Mexico State and Morelos; (7) Central east: Hidalgo, Puebla and Tlaxcala; (8) Gulf: Tabasco and Veracruz; (9) South: Chiapas, Guerrero and Oaxaca; (10) Southeast: Campeche, Quintana Roo and Yucatan. Except for the Gulf region dummy, all dummy variables are included as regressors. 